\title{
Tanggung Jawab dan Perlindungan Hukum Terhadap Werda Notaris
}

\author{
Chandra Novita \\ cnovita156@gmail.com
}

\begin{abstract}
The problems raised in this study are, first, what sort of liability does a notary having his term of office ended have against the deed made before the end of his term? Second, how is the legal protection of a retired notary in relation to the deed made before the term ending? This research is analyzed qualitatively in the form of descriptive research, and this study uses a legislative approach and a case approach with empirical juridical research. The results indicate that, first, the liability of a notary whose term of office has ended against violations of notary laws can be either administrative, civil, or criminal with various sanctions. Second, the legal protection for a retired notary in relation to the deed he makes before/after the term of office can include legal protection from the notary himself, legislative regulations, articles of criminal prosecution, and protection from the Indonesian Notary Association (INI).
\end{abstract}

Keywords: Retired notary; notary liability; notary legal protection

\begin{abstract}
Abstrak
Permasalahan yang diangkat dalam penelitian ini pertama, bagaimana bentuk pertanggungjawaban notaris yang telah berakhir masa jabatannya terhadap akta yang dibuatnya sebelum berakhir masa jabatannya? Kedua, bagaimana perlindungan hukum terhadap notaris yang telah berakhir masa jabatannya sehubungan atas akta yang dibuat sebelum werda. Penelitian ini dianalisis secara kualitatif dalam bentuk laporan hasil penelitian yang bersifat deskriptif dan pendekatan penelitian ini adalah pendekatan perundang-undangan dan pendekatan kasus dengan jenis penelitian yuridis empiris. Dari hasil analisis penelitian ini menyimpulkan bahwa pertama, bentuk tanggung jawab notaris yang telah berakhir masa jabatannya terhadap pelanggaran undang-undang jabatan notaris, dapat dipertanggungjawabkan baik secara administrasi, perdata dan pidana serta macam-macam sanksinya. Kedua, perlindungan hukum terhadap notaris yang telah berakhir masa jabatannya sehubungan atas akta yang dibuatnya sebelum/sesudah werda yaitu berupa perlindungan dari notaris itu sendiri, regulasi peraturan perundang-undangan, pasal-pasal pidana daluwarsa penuntutan dan bagian pengayoman dari lkatan Notaris Indonesia (INI).
\end{abstract}

Kata-kata Kunci: Notaris werda; tanggung jawab notaris; perlindungan hukum notaris 


\section{Pendahuluan}

Jabatan merupakan suatu bidang pekerjaan atau tugas yang dilakukan seseorang untuk melakukan pekerjaannya serta jabatan tersebut diatur dalam sebuah peraturan yang mengenai bidang pekerjaan tersebut. ${ }^{1}$ Menurut arti dalam kamus besar Indonesia, bahwa jabatan berarti pekerjaan (tugas) dalam pemerintahan atau organisasi. Jabatan dalam arti sebagai $a m b t^{2}$ merupakan fungsi tugas, wilayah kerja pemerintah pada umumnya atau badan perlengkapan pada khususnya.

Pasal 1 angka 1 Undang-Undang Nomor 2 Tahun 2014 tentang Perubahan atas Undang-Undang Nomor 30 Tahun 2004 tentang Jabatan Notaris (UUJN) menyatakan bahwa Notaris adalah pejabat umum yang berwenang untuk membuat akta autentik dan memiliki kewenangan lainnya sebagaimana di maksud dalam undang-undang ini atau berdasarkan undang-undang lainnya. Bahwa dalam pasal tersebut Notaris merupakan suatu jabatan yang telah diatur dalam peraturan perundang-undangan.

Notaris sebagai profesi yang tugasnya atau kewenangannya diberikan oleh undang-undang, seharusnya menggunakan prinsip kehati-hatian untuk menghindarkan dari kesalahan ataupun kelalaian yang bisa saja terjadi. Ketika notaris salah ataupun lalai dalam menjalankan jabatannya dengan melanggar peraturan perundang-undangan yang telah ada, maka sepatutnya notaris bertanggungjawab atas kesalahan maupun kelalaiannya. Dewasa ini, kurangnya kesadaran notaris untuk bertanggungjawab secara langsung atas perbuatan yang telah dilakukkannya. Sehingga untuk menyadarkan Notaris tersebut harus menggunakan lembaga peradilan, dengan cara menjadikan Notaris sebagai tergugat atau turut tergugat karena melakukan perbuatan melawan hukum.

Gugatan yang berkenaan dengan ganti rugi berkaitan dengan materi yang kemudian diatur dalam berbagai peraturan perundang-undangan, salah satunya Undang-Undang Nomor 30 Tahun 2004 tentang Jabatan Notaris sebagaimana yang

\section{$\operatorname{hlm} 2$.}

${ }^{1}$ Habib Adjie, Sekilas Dunia Notaris \& PPAT Indonesia (Kumpulan Tulisan), CV Badar Maju, Bandung, 2009,

${ }^{2}$ Habib Adjie, Sanksi Perdata dan Administrasi Terhadap Notaris Sebagai Pejabat Publik, PT Refika Aditama, Bandung, 2008, hlm. 16. 
telah diubah dengan Undang-Undang Nomor 2 Tahun 2014, selain itu juga didasarkan kepada Pasal 1365 KUHPerdata. Namun dengan lahirnya berbagai undang-undang yang secara khusus mengatur mengenai tuntutan ganti kerugian, maka telah terjadi perubahan dalam penerapan Pasal 1365 KUHPerdata. ${ }^{3}$

Sebagai contoh bagaimana Notaris dapat terlibat dalam kasus perdata terkait akta otentik yang sudah dikeluarkannya adalah kasus perdata yang terjadi di Kabupaten Sleman Yogyakarta. Tindakan tersebut dilakukan oleh seorang pensiunan Notaris PPAT di Kabupaten Sleman Yogyakarta, dikarenakan Notaris ceroboh dan tidak cermat bekerja. Kejadian 14 November 2017 tersebut mengakibatkan yang bersangkutan melalui Pengadilan Negeri Sleman dihukum selama 1 tahun. ${ }^{4}$

Hal tersebut disebabkan oleh kelalaian seorang notaris karena kurang seksama atau kurang cermat dalam mencocokan identitas para pihak dengan aslinya. Kelalaian dalam melakukan suatu perbuatan adalah ketika seseorang tidak melakukan suatu perbuatan. Dengan sikap demikian hakikatnya dia telah melawan hukum, sebab semestinya ia harus berbuat dan melakukan suatu perbuatan. Oleh karena itu notaris juga harus menjalankan tugas jabatannya dapat dipertanggungjawabkan secara administrasi, perdata dan pidana. Begitu juga sanksi-sanksi yang harus diterima berupa sanksi administrasi, perdata dan pidana.

Notaris yang merupakan jabatan yang diatur dalam undang-undang mempunyai kewenangan dan kewajiban yang harus dipenuhi sebagaimana diatur di dalam UUJN. Kewenangan dan kewajiban Notaris tersebut diatur dalam Pasal 15 ayat (2) sampai huruf e dan Pasal 16 ayat (1) huruf a UUJN.

Akta otentik yang dibuat oleh Notaris juga diperhatikan dalam definisi KUHPerdata yaitu Pasal 1868 yang menjelaskan bahwa:

"Suatu akta otentik adalah suatu akta yang dibuat dalam bentuk yang ditentukan oleh Undang-Undang oleh atau dihadapan pejabat umum yang berwenang untuk itu di tempat akta itu dibuat."

\footnotetext{
${ }^{3}$ Habib Adjie (II), Sanksi Perdata dan Administratif Terbadap Notaris Sebagai Pejabat Publik, Refika Aditama, Bandung, 2008, hlm. 83.

4 http://www.mediarakyat.co.id/2017/11/notaris-ceroboh-tidak-cermat-kerja.html diakses pada tanggal 20 November 2017
} 
Dari unsur Pasal 1868 tersebut salah satunya menyebutkan tentang pembuatan akta otentik dibuat oleh atau di hadapan pejabat umum. Hal ini menjelaskan Notaris salah satu jabatan yang berwenang membuat akta otentik.

Akta otentik sendiri dalam dunia kenotariatan terdiri dari acte ambtelijk dan partijacte, acte ambtelijk (pejabat) merupakan akta yang dibuat oleh pejabat yang di beri wewenang untuk itu, pejabat tersebut menerangkan apa yang dilihat serta apa yang dilakukannya, sedangkan Partij Acte (para pihak) adalah akta yang dibuat dihadapan pejabat yang di beri wewenang untuk itu. ${ }^{5}$ Akta otentik Notaris merupakan sebuah minuta akta yaitu asli akta Notaris. Minuta akta adalah kesatuan dari Protokol Notaris yang merupakan dokumen negara yang harus di pelihara. Memelihara Protokol Notaris juga tidak sembarangan dan Notaris mempunyai pengawasan khusus yang telah diatur dalam UUJN.

Selanjutnya, Notaris dalam melakukan jabatannya mempunyai suatu pengawasan yang diatur dalam UUJN dan dilakukan oleh Majelis Pengawas Notaris (MPN). MPN tersebut juga dibagi menjadi 3 bidang atau tingkatan yaitu Majelis Pengawas Daerah (MPD), Majelis Pengawas Wilayah (MPW) dan Majelis Pengawas Pusat (MPP). Kewenangan MPD salah satunya menentukan tempat penyimpanan Protokol Notaris yang pada saat serah terima Protokol Notaris telah berumur 25 tahun atau lebih. Hal tersebut diatur lebih lanjut dalam Peraturan Menteri Hukum dan Hak Asasi Manusia Republik Indonesia Nomor M.02.PR.08.10 Tahun 2004 tentang Tata Cara Pengangkatan Anggota, Pemberhentian Anggota, Susunan Organisasi, Tata Kerja dan Tata Cara Pemeriksaan Majelis Pengawas Notaris.

Notaris mempunyai tanggung jawab atas jabatannya yang harus dijalankan sesuai UUJN ataupun undang-undang lainnya juga bisa mengalami berhentinya suatu jabatan. Pasal 8 ayat (1) huruf b dan ayat (2) UUJN, Notaris berhenti atau diberhentikan dari jabatannya dengan hormat apabila Notaris tersebut telah berumur 65 tahun. Notaris dapat pula mengajukan kepada Menteri Hukum dan Hak Asasi Manusia untuk memperpanjang masa jabatan selama 2 tahun dengan mempertimbangkan kesehatan yang bersangkutan. Hal ini dapat disimpulkan

\footnotetext{
${ }^{5}$ Abdul Ghofur Anshori, Lembaga Kenotariatan Indonesia, UII Press, Yogyakarta, 2009, hlm. 22.
} 
bahwa dari undang-undang tersebut bahwa masa bakti seorang Notaris dalam menjalankan hak dan kewajibannya tidak bisa melebihi umur 67 tahun.

Adapun bentuk dari pertanggungjawaban seorang Notaris selaku pejabat umum yang berhubungan dengan kebenaran materiil, dibedakan menjadi empat poin, yaitu: ${ }^{6}$

1. Tanggung jawab Notaris secara perdata terhadap kebenaran materiil terhadap akta yang dibuatnya;

2. Tanggung jawab Notaris secara pidana terhadap kebenaran materiil dalam akta yang dibuatnya;

3. Tanggung jawab Notaris berdasarkan peraturan jabatan Notaris (UUJN) terhadap kebenaran materiil dalam akta yang dibuatnya;

4. Tanggung jawab Notaris dalam menjalankan tugas jabatannya berdasarkan kode etik Notaris.

Selain memenuhi syarat yang telah ditentukan undang-undang agar suatu akta menjadi otentik, seorang Notaris dalam melaksanakan tugasnya tersebut wajib. Apa yang tertuang dalam awal dan akhir akta yang menjadi tanggung jawab Notaris adalah ungkapan yang mencerminkan keadaan yang sebenar-benarnya pada saat pembuatan akta.

Pasal 62 huruf $\mathrm{b}$ menyebutkan bahwa penyerahan Protokol Notaris dilakukan dalam hal Notaris, yaitu telah berakhir masa jabatannya. Berakhirnya masa jabatan seorang Notaris tidak mengakhiri tanggung jawab Notaris terhadap akta yang dibuatnya. Pihak Penyimpan Protokol Notaris tersebut adalah Notaris lain yang ditunjuk oleh MPD berdasarkan Permenkumham Nomor M.02.PR.08.10 Tahun 2004 tentang Tata Cara Pengangkatan Anggota, Pemberhentian Anggota, Susunan Organisasi, Tata Kerja dan Tata Cara Pemeriksaan Majelis Pengawas Notaris. Peraturan tentang apa yang telah disebutkan dalam Pasal 65 UUJN tersebut diatas merupakan peraturan secara ketentuan hukum. Penulis dalam penelitian ini akan membahas bagaimana suatu peraturan tersebut sudah sesuai atau belum dalam praktik di dunia kenotariatan.

Notaris yang telah berakhir masa jabatannya tetap harus bertanggung jawab terhadap akta yang dibuatnya sesuai dengan penjelasan dalam Pasal 65 UUJN,

${ }^{6}$ Ibid., hlm. 34. 
namun tidak terdapat perlindungan hukum terhadapnya. UUJN tidak mengatur secara khusus mengenai perlindungan hukum bagi Notaris yang telah berakhir masa jabatannya, sehingga dalam hal ini terjadi kekosongan hukum.

Meskipun Notaris telah berakhir masa jabatannya sehubungan adanya masalah terkait akta yang dibuatnya salah satunya dapat dipertanggungjawabkan secara perdata, yang dalam praktiknya Notaris sering dijadikan atau didudukan sebagai tergugat oleh pihak lainnya, yang merasa bahwa tindakan hukum yang dilakukannya tersebut dalam akta dikategorikan sebagai tindakan atau perbuatan hukum Notaris bersama-sama pihak lain yang juga tersebut dalam akta. Dalam konteks hukum kenotariatan, tugas Notaris hanyalah memformulasikan dan mengkonstatir apa keinginan para penghadap ke dalam bentuk akta otentik, dengan memperhatikan hukum yang berlaku.

Dari permasalahan tersebut diatas maka penelitian ini akan mengkaji aspek hukum mengenai bentuk pertanggungjawaban Notaris yang telah berakhir masa jabatannya terhadap akta yang dibuatnya dan perlindungan hukum terhadap Notaris yang telah berakhir masa jabatannya sehubungan atas akta yang dibuatnya sebelum atau sesudah werda dengan suatu bentuk penelitian.

\section{Rumusan Masalah}

Berdasarkan uraian dan latar belakang masalah di atas, maka penulis tertarik untuk membahas masalah tersebut lebih lanjut dengan menitikberatkan pada rumusan masalah: pertama, bagaimana bentuk pertanggungjawaban Notaris yang telah berakhir masa jabatannya terhadap akta yang dibuatnya sebelum berakhir masa jabatannya? Kedua, bagaimana perlindungan hukum terhadap Notaris yang telah berakhir masa jabatannya sehubungan atas akta yang dibuatnya sebelum/sesudah Werda?

\section{Tujuan Penelitian}

Dari perumusan permasalahan yang telah diuraikan diatas, maka penulis akan menjelaskan tujuan yang hendak dipakai, yaitu pertama, untuk mengetahui dan menganalisis bentuk pertanggungjawaban Notaris yang telah berakhir masa jabatannya terhadap akta yang dibuatnya atau dibuat oleh dihadapannya sebelum 
berakhir masa jabatannya. Kedua, untuk mengetahui dan menganalisis bentuk perlindungan hukum terhadap Notaris yang telah berakhir masa jabatannya sehubungan adanya masalah terkait akta yang dibuatnya ketika belum Werda.

\section{Metode Penelitian}

Penelitian ini pada dasarnya adalah penelitian dekriptif kualitatif berjenis empiris dengan menggunakan pendekatan undang-undang (statute approach) dan pendekatan kasus (case approach) yang oleh karenanya digunakan dua sumber data dalam pembahasannya. Sumber data primer dikumpulkan dengan metode kepustakaan berasal dari peraturan-peraturan hukum yang membahas mengenai tanggung jawab dan perlindungan hukum Notaris Werda terhadap akta yang telah dibuat atau dihadapannya. Selain sumber data primer, sumber data sekunder mutlak dibutuhkan sebagai penegasan dari implementasi peraturan yang telah dibuat. Untuk melengkapinya, sumber data sekunder dikumpulkan dengan penelitian lapangan mengkaji mengenai kasus yang melibatkan Notaris Werda di Kabupaten Sleman dalam mempertanggungjawabkan akta yang telah dibuat atau dihadapnya sebelum pensiun. Data-data tersebut dikumpulkan dengan dokumentasi keputusan Mahkamah Agung, wawancara dengan hakim terkait dan anggota dari Ikatan Notaris Indonesia (INI).

\section{Hasil Penelitian dan Pembahasan}

Bentuk Pertanggungjawaban Notaris yang Telah Berakhir Masa Jabatannya Terhadap Akta yang dibuatnya Sebelum Berakhir Masa Jabatannya.

Tanggungjawab notaris dalam menjalankan tugasnya terhadap pelanggaran jabatan notaris beserta macam-macam sanksi seperti pertanggungjawaban administrasi, perdata, dan pidana. Sanksi merupakan tindakan hukuman untuk memaksa individu menepati perjanjian atau mentaati ketentuan undang-undang. ${ }^{7}$ Setiap aturan hukum yang berlaku, selalu ada sanksi yang menyertainya pada akhir aturan hukum tersebut. Pada hakikatnya pemberian sanksi sebagai suatu

Departemen Pendidikan Nasional, Kamus Besar Bahasa Indonesia, Gramedia Pustaka Utama, Jakarta, 2008, 
paksaan ini berguna untuk menyadarkan masyarakat atau pihak, bahwa tindakan yang telah dilakukannya tersebut telah melanggar ketentuan aturan hukum yang berlaku.

Begitu pula sanksi yang ditujukan terhadap notaris, hal ini semata-mata sebagai bentuk penyadaran kepada notaris bahwa dalam menjalankan jabatannya maka seorang notaris harus mengacu kepada ketentuan hukum yang berlaku. Dalam melaksanakan jabatannya, notaris tidak boleh melanggar ketentuanketentuan mengenai pelaksanaan tugas jabatan notaris sebagaimana yang tercantum dalam UUJN. Pemberian sanksi terhadap notaris juga merupakan upaya perlindungan yang diberikan kepada masyarakat, agar terhindar dari tindakan notaris yang merugikan. Sanksi tersebut juga memiliki fungsi untuk menjaga martabat lembaga notaris sebagai lembaga kepercayaan, karena karena kepercayaan masyarakat dapat turun apabila notaris tersebut melakukan pelanggaran.

Setidaknya tanggung jawab notaris dibagi menjadi tiga ranah besar yakni tanggung jawab secara administrasi, perdata, dan pidana. Dibawah ini dijelaskan mengenai ketiganya.

\section{Pertanggungjawaban Secara Administrasi}

Notaris adalah pejabat umum yang berwenang untuk membuat akta otentik. Sebagai pejabat umum notaris diberi kewenangan oleh undang-undang untuk membuat akta otentik mengenai semua perbuatan, perjanjian, dan ketetapan yang diharuskan oleh peraturan perundang-undangan dan/atau yang dikehendaki oleh yang berkepentingan untuk dinyatakan dalam akta otentik, menjamin kepastian tanggal pembuatan akta, menyimpan akta. Memberikan grosse akta, salinan dan kutipan akta, semuanya itu sepanjang pembuatan akta-akta itu tidak juga ditugaskaan atau dikecualikan kepada pejabat lain atau orang lain yang ditetapkan oleh undang-undang. ${ }^{8}$

Pejabat umum yang dimaksud dalam Pasal 1 angka 1 UUJN harus dibaca sebagai pejabat publik atau notaris sebagai pejabat publik yang berwenang untuk membuat akta otentik sesuai Pasal 15 ayat (1) UUJN dan kewenangan lainnya

${ }^{8}$ Habib Adjie (I), Hukum Notaris Indonesia, Tafsir Tematik Terbadap Undang-Undang Nomor 30 Tabun 2004 tentang Notaris, Refika Aditama, Surabaya, 2007, hlm. 13. 
sebagiamana dimaksud dalam Pasal 15 ayat (2) dan (3) UUJN dan untuk melayani kepentingan masyarakat. Profesi notaris adalah menjalankan sebagian tugas negara, khususnya yang berkaitan dengan keperdataan, yang dilindungi oleh undang-undang. ${ }^{9}$

Tanggungjawab notaris secara administrasi dapat diatur secara rinci dalam UUJN. Notaris ditugaskan dan bertanggungjawab untuk melakukan pendaftaran dan mengesahkan (waarmerken dan legalisasi) surat-surat/akta yang dibuat di bawah tangan. Apabila ketentuan itu tidak diindahkan, maka akan menimbulkan akibat hukum, akta yang dibuat oleh notaris dapat menjadi akta di bawah tangan dan akta tersebut dapat dibatalkan atau batal demi hukum. Tanggung jawab administrasi notaris akan muncul ketika kewajiban-kewajiban notaris tidak diindahkan sebagaimana mestinya.

Pertanggungjawaban notaris secara administrasi dapat dimintakan melalui lembaga/organisasi notaris, berbeda dengan pertanggungjawaban pidana dan perdata yang harus dilakukan melalui pengadilan. Walaupun demikian, pengadilan melalui amar putusannya dapat meneruskannya kepada organisasi notaris untuk menindaklanjuti putusan yang telah dikeluarkan oleh pengadilan. Menentukan adanya suatu pertanggungjawbaan administrasi notaris yaitu harus adanya perbuatan notaris tersebut yang dapat dihukum atau perbuatannya yang telah melanggar unsur-unsur secara tegas diatur dalam UUJN. Akta otentik dapat dikualifikasikan telah melanggar syarat administrasi apabila dalam pembuatan akta tersebut tidak sesuai dengan ketentuan Pasal 38, 39 dan 40 UUJN.

Menuntut pertanggungjawaban notaris, dilakukan dengan cara menjatuhkan atau memberikan notaris berupa sanksi administratif untuk mempertanggungjawabkan pelanggaran yang telah dilakukannya. Sanksi administratif bagi notaris yang diatur di dalam UUJN telah ditentukan sebagai berikut:

1) Teguran lisan;

2) Teguran tertulis;

3) Pemberhentian sementara; 
4) Pemberhentian dengan hormat;

5) Pemberhentian tidak hormat.

Penjatuhan sanksi-sanksi sebagaimana terurai di atas terhadap notaris yang melanggar ketentuan dalam pembuatan akta otentik disesuaikan dengan kuantitas dan kualitas pelanggaran yang dilakukan anggota tersebut. Pengenaan sanksi pemberhentian sementara demikian juga sanksi pemecatan maupun pemberhentian dengan tidak hormat terhadap pelanggaran sebagaimana dimaksud dalam UUJN dilakukan secara bertahap dan berkesinambungan.

Sanksi terhadap notaris berupa pemberhentian sementara dari jabatannya dimaksudkan agar notaris tidak melaksanakan tugas jabatannya untuk sementara waktu sebelum sanksi berupa pemberhentian dengan hormat atau pemberhentian tidak hormat dijatuhkan pada notaris. Pemberian sanksi ini dapat berakhir dalam bentuk pemulihan kepada notaris untuk melaksanakan tugas jabatannya kembali atau ditindaklanjuti dengan sanksi pemberhentian dengan hormat atau pemberhentian tidak hormat. Untuk memberikan kepastian maka pemberhentian sementara tersebut harus ditentukan batas waktunya, sehingga nasib notaris tidak digantung. Sanksi pemberhentian sementara ini merupakan paksaan nyata, sedangkan sanksi pemberhentian dengan hormat atau pemberhentian dengan tidak hormat ini masuk kedalam ranah sanksi pencabutan keputusan yang menguntungkan.

Prinsipnya, selain meminta pertanggungjawaban hukum secara administrasi bagi notaris yang melanggar UUJN, Majelis Pengawas Notaris seharusnya menjalankan amanat UUJN dengan tujuan agar notaris yang bersangkutan tidak mengulangi lagi perbuatannya. Pembinaan merupakan suatu tindakan, proses, hasil atau pernyataan menjadi lebih baik, pembinaan menunjukan adanya kemajuan, peningkatan, perubahan, evolusi atas berbagi kemungkinan, berkembang, atau peningkataan atas sesuatu. ${ }^{10}$

\section{Pertanggungjawaban Secara Perdata}

Notaris sehubungan dengan kewenangannya, dapat dibebani tanggungjawab atas perbuatannya berupa pembuatan akta otentik yang tidak sesuai dengan ketentuan yang berlaku atau dilakukan secara melawan hukum. Berkaitan dengan

${ }^{10}$ Miftah Thoha, Manajemen Kepegawaian Sipil di Indonesia, Kencana Press, Jakarta, 1999, hlm. 7. 
wewenang tersebut, jika notaris melakukan tindakan di luar wewenang yang telah ditentukan, maka akta notaris tersebut tidak mengikat secara hukum atau tidak dapat dilaksanakan. Pihak yang merasa dirugikan oleh tindakan notaris tersebut, dapat menggugat notaris secara perdata ke Pengadilan Negeri atau Pengadilan Agama.

KUHPerdata juga mengatur tanggung jawab hukum secara perdata. Pertanggungjawaban itu muncul dari undang-undang (sebagai perbuatan melawan hukum) maupun dari perjanjian-perjanjian, sebagaimana juga dengan KUHPerdata di negara-negara lain dalam sistem hukum Eropa Kontinental. Dengan demikian model tanggung jawab hukum yang muncul akibat perbuatan melawan hukum menurut KUHPerdata adalah:

1. Tanggungjawab dengan unsur kesalahan (kesengajaan dan kelalaian), sebagaimana yang terdapat dalam Pasal 1365 KUHperdata.

2. Tanggungjawab dengan unsur kesalahan, khususnya unsur kelalaian, sebagaimana yang terdapat dalam Pasal 1366 KUHPerdata;

3. Tanggungjawab mutlak (tanpa kesalahan) dalam arti yang sangat terbatas ditemukan dalam Pasal 1367 KUHPerdata.

Selain yang harus dipertanggungjawabkan, ada juga sanksi secara keperdataan yang harus diterima ialah sanksi yang dijatuhkan terhadap kesalahan yang terjadi akibat wanprestasi maupun perbuatan yang melanggar hukum onrechtmatige daad. Sanksi secara keperdataan dapat berupa penggantian biaya, ganti rugi dan bunga. Notaris akan dimintakan sanksi apabila mendapat gugatan dari para penghadap yang merasa dirugikan akibat akta yang bersangkutan cacat hukum, sehingga mempunyai kekuatan pembuktian sebagai akta dibawah tangan atau batal demi hukum.

Akta notaris memiliki kekuatan pembuktian sempurna, namun apabila dilanggar ketentuan tertentu, maka akan terdegradasi nilai pembuktiannya menjadi akta di bawah tangan. Pasal 1869 KUHPerdata menentukan batasan akta notaris yang mempunyai kekuatan sebagai akta di bawah tangan dapat terjadi jika tidak memenuhi ketentuan:

1) Tidak berwenangnya pejabat yang bersangkutan

2) Tidak mempunyai pejabat umum yang bersangkutan

3) Cacat dalam bentuknya 
Akta di bawah tangan memiliki nilai pembuktian yang sempurna sepanjang para pihak mengakuinya. Apabila para pihak melanggar ketentuan tertentu seperti yang tercantum dalam UUJN, maka akta yang bersangkutan tetap mempunyai kekuatan pembuktian yang sempurna serta mengikat para pihak.

Suatu akta yang dinyatakan batal demi hukum, maka akta tersebut dianggap tidak pernah ada atau tidak pernah dibuat, sesuatu yang tidak pernah dibuat tidak dapat dijadikan sebagai dasar suatu tuntutan dalam bentuk kompensasi kerugian yang biasanya berupa penggantian biaya, ganti rugi dan bunga. Akta notaris yang batal demi hukum tidak dapat dimintakan untuk memberikan penggantian biaya, ganti rugi dan bunga.

Penggantian biaya, ganti rugi dan bunga dapat digugat kepada notaris dengan mendasarkan pada hubungan hukum notaris dengan para pihak yang menghadap notaris. Apabila ada pihak yang merasa dirugikan dari akta yang dibuat oleh notaris, maka yang bersangkutan dapat secara langsung mengajukan tuntutan secara perdata terhadap notaris tersebut sehingga notaris tersebut dapat bertanggung jawab secara perdata atas akta yang dibuatnya. Tuntutan penggantian biaya, ganti rugi dan bunga terhadap notaris, tidak didasarkan pada kedudukan alat bukti yang berubah karena melanggar ketentuan tertentu dalam UUJN, tetapi didasarkan kepada hubungan hukum yang terjadi antara notaris dan para pihak yang menghadap notaris tersebut. Sekalipun notaris tersebut telah purna bakti, notaris tersebut tetap harus bertanggung jawab secara perdata terhadap akta yang pernah dibuatnya.

Dalam praktiknya, notaris sering dijadikan atau didudukkan sebagai tergugat oleh pihak lainnya, yang merasa bahwa tindakan hukum yang dilakukannya tersebut dalam akta dikategorikan sebagai tindakan atau perbuatan hukum notaris bersama-sama pihak lain yang juga tersebut dalam akta. Dalam konteks hukum kenotariatan, tugas notaris hanyalah memformulasikan keinginan para penghadap ke dalam bentuk akta otentik, dengan memperhatikan hukum yang berlaku. Berdasarkan substansi tersebut, maka sudah jelas apabila akta yang dibuat oleh notaris tersebut bermasalah oleh para pihak sendiri, maka notaris tidak perlu dilibatkan dalam hal ini, karena notaris bukanlah pihak dalam akta. 
Pengingkaran tersebut dapat dilakukan dengan jalan mengajukan gugatan secara perdata terhadap notaris ke pengadilan, dan para pihak tersebut wajib membuktikan hal-hal yang ingin diingkarinya, sedangkan notaris wajib mempertahankan aspek-aspek tersebut. Dalam hal ini perlu dipahami kaidah hukum notaris yaitu akta notaris sebagai akta otentik, dimana akta tersebut mempunyai kekuatan pembuktian sempurna, sehingga apabila ada orang atau pihak yang ingin mengingkarinya atau menyatakan bahwa akta tersebut tidak benar adanya, maka pihak tersebut wajib baginya untuk membuktikan penilaian atau pernyataannya sesuai dengan aturan hukum yang berlaku.

Sesuai dengan konstruksi hukum kedudukan notaris di Indonesia, yang pertama yaitu Notaris bukanlah sebagai pihak dalam akta, dan notaris hanya memformulasikan keinginan para pihak agar tindakannya dituangkan ke dalam bentuk akta otentik, yaitu akta yang dibuat oleh dan di hadapan notaris. Berdasarkan konstruksi hukum seperti itu, sangat sulit diterima berdasarkan logika apabila seorang notaris dijadikan sebagai tergugat berkaitan dengan akta yang dibuat dihadapan notaris. Notaris memiliki kewenangan untuk melaksanakan tugas jabatannya selama kewenangan tersebut melekat pada dirinya. Batas pertanggung jawaban notaris ialah selama/sepanjang notaris memiliki kewenangan. Notaris yang sedang cuti, purna bakti dan yang telah diberhentikan tidak dapat dimintai lagi pertanggungjawabannya, karena sudah tidak ada kewenangan lagi pada dirinya. ${ }^{11}$

\section{Pertanggungjawaban Secara Pidana}

Dalam praktek kerap kali ditemukan, apabila ada akta notaris dipermasalahkan oleh para pihak atau pihak yang lain kerap kali notaris ditarik pula sebagai pihak yang turut serta melakukan atau membantu melakukan suatu tindak pidana, yaitu memberikan keterangan palsu ke dalam akta notaris. Dengan adanya hal tersebut maka menimbulkan kerancuan, apakah mungkin notaris secara sengaja culpa atau khilaf bersama-sama para pihak membuat akta yang

${ }^{11}$ Habib Adjie, Hukum Notaris Indonesia, Op. Cit., hlm. 23. 
diniatkan untuk melakukan suatu tindak pidana. Apabila notaris terbukti melanggar hal tersebut, maka wajib banginya untuk diberikan sanksi.

Kaitannya dengan hal diatas, maka untuk meminta keterangan notaris atas laporan pihak tertentu menurut Pasal 66 UUJN maka jika notaris dipanggil oleh Kepolisian, Kejaksaan, atau Hakim maka instansi yang ingin memanggil wajib meminta persetujuan Majelis Kehormatan Notaris. ${ }^{12}$ Ketentuan Pasal 66 UUJN tersebut bersifat imperatif bagi pihak Kepolisian, Kejaksaan, atau Hakim, yang artinya bahwa apabila pihak Kepolisian, Kejaksaan, dan Hakim menyepelekan ketentuan Pasal 66 UUJN maka dapat dikategorikan sebagai pelanggaran terhadap undang-undang. Ketika seorang tidak diizinkan untuk dipanggil, maka pihak Kepolisian atau Kejaksaan akan memanggil saksi-saksi akta notaris yang tersebut pada bagian akhir akta. Hal tersebut sebenarnya tidak sesuai dengan hukum kenotariatan yang berlaku, karena saksi tersebut termasuk ke dalam aspek formal Notaris yang merupakan bagian yang tidak terpisahkan dari akta notaris itu sendiri.

UUJN tidak mengatur sanksi pidana terhadap notaris, maka apabila terjadi pelanggaran pidana oleh notaris dapat dikenakan sanksi yang terdapat dalam KUHP, dengan catatan pemidanaan notaris dilakukan dengan batasan:

1) Ada tindakan hukum dari notaris terhadap aspek lahiriah, formal, materiil akta yang disengaja, penuh kesadaran, serta direncanakan bahwa akta yang akan dibuat dihadapan notaris atau oleh notaris bersama-sama para penghadap dijadikan dasar untuk melakukan tindak pidana. Nilai pembuktian akta notaris dari aspek lahiriah ialah, bahwa akta tersebut harus dilihat apa adanya, jika ada yang menilai akta notaris tidak memenuhi syarat sebagai akta maka yang bersangkutan wajib membuktikannya. Sedangkan akta notaris dalam aspek formal harus memberikan kepastian, bahwa sesuatu kejadian dan fakta yang tertuang dalam akta tersebut betul-betul dilakukan oleh notaris dan diterangkan oleh pihak-pihak yang menghadap pada saat yang tercantum dalam akta. Secara aspek materiil kepastian tentang materi suatu akta, bahwa apa yang tersebut dalam akta merupakan pembuktian yang sah terhadap pihak-pihak yang membuat akta.

2) Ada tindakan hukum dari notaris dalam membuat akta dihadapan atau oleh notaris yang apabila diukur berdasarkan UUJN tidak sesuai dengan UUJN.

3) Tindakan notaris tersebut tidak sesuai menurut instansi yang berwenang untuk menilai tindakan suatu notaris, dalam hal ini Majelis Pengawas Notaris. ${ }^{13}$ 
Pertanggungjawaban pidana terhadap notaris dapat dimintakan jika ketiga syarat sebagaimana tersebut di atas terpenuhi secara kolektif, artinya di satu sisi notaris memenuhi unsur telah melakukan suatu pelanggaran terhadap KUHP dan di sisi lain notaris juga melakukan pelanggaran terhadap UUJN.

Sementara itu untuk menentukan suatu pertanggungjawaban notaris secara pidana, maka perbuatan notaris tersebut harus sudah terpenuhi 3 syarat berikut ini:

1) Harus ada perbuatan notaris yang dapat di hukum karena melanggar unsurunsur dalam pembuatan suatu akta otentik yang secara tegas dirumuskan oleh undang-undang.

2) Perbuatan notaris tersebut bertentangan dengan hukum, dan perbuatan tersebut dilakukan dengan kesalahan (baik itu unsur kesengajaan maupun kelalaian) dari notaris tersebut.

3) Kesalahan atau kelalaian dalam tindak pidana meliputi unsur-unsur yang bertentangan dengan hukum dan harus ada perbuatan melawan hukum pidana.

Penjatuhan sanki pidana terhadap notaris dapat dilakukan sepanjang batasanbatasan tersebut dilanggar. Artinya di samping memenuhi rumusan pelanggaran tersebut dalam UUJN, juga harus memenuhi rumusan dalam KUHP. Pemeriksaan kepada notaris harus dapat dibuktikan kesalahan yang dilakukan oleh notaris tersebut secara intelektual, dalam hal ini kekuatan logika hukum sangat diperlukan dalam proses pemeriksaan notaris. Hal tersebut berlaku pula bagi notaris yang sudah tidak menjabat lagi ataupun pensiun. Sehingga apabila ada akta notaris yang bermasalah oleh para pihak yang mempermasalahkan, maka kepadanya wajib untuk membuktikannya. Namun apabila di Pengadilan notaris tersebut terbukti dengan sengaja atau tidak sengaja, secara bersama-sama dengan para pihak penghadap membuat akta dengan maksud dan tujuan untuk menguntungkan pihak atau penghadap tertentu dan kemudian merugikan pihak yang lain, maka kepadanya wajib dijatuhkan hukuman sesuai ketentuan yang mengatur hal tersebut. ${ }^{14}$ hlm. 92 .

${ }^{14}$ M. Luthfan Hadi Darus, Hukum Notariat dan Tanggungjawab Jabatan Notaris, UII Press, Yogyakarta, 2017, 


\section{Perlindungan Hukum Bagi Notaris yang Telah Berakhir Masa Jabatanya}

Jabatan notaris dibatasi oleh waktu, sebagaimana ketentuan Pasal 8 UUJN yang berbunyi:

a. Notaris berhenti atau diberhentikan dari jabatannya dengan hormat karena:

1) meninggal dunia

2) telah berumur 65 tahun;

3) permintaan sendiri;

4) tidak mampu secara rohani dan/ atau jasmani untuk melaksanakan tugas

5) jabatan Notaris secara terus-menerus lebih dari 3 tahun;

6) merangkap jabatan sebagaimana dimaksud dalam Pasal 3 huruf $g$.

b. Ketentuan umur sebagaimana dimaksud pada ayat (1) huruf b dapat diperpanjang sampai berumur 67 tahun dengan mempertimbangkan kesehatan yang bersangkutan.

Memperhatikan ketentuan perlindungan hukum sebagaimana diatur dalam UUJN tersebut di atas berlaku ketika notaris masih menduduki jabatan sebagai pejabat umum. Setelah berakhir masa jabatannya, tidak ada ketentuan di dalam UUJN yang menjelaskan tentang perlindungan hukum terhadap notaris yang telah berakhir masa jabatannya. Sedangkan dari segi pertanggungjawaban, secara jelas dinyatakan dalam Pasal 65 UUJN, bahwa: Notaris, Notaris Pengganti, Notaris Pengganti Khusus, dan Pejabat Sementara bertanggung jawab atas setiap akta yang dibuatnya meskipun protokol Notaris diserahkan atau dipindahkan kepada pihak penyimpan protokol.

Hal ini menunjukkan bahwa ketentuan undang-undang menentukan tanggung jawab notaris tidak berakhir dengan berakhirnya masa jabatannya. Tetapi dalam hal perlindungan sehubungan dengan pertanggungjawaban yang tidak berakhir tersebut tidak dijelaskan dalam peraturan perundang-undangan. Sesuai dengan ketentuan Pasal 65 UUJN tersebut, walaupun Notaris tersebut telah berhenti dari jabatannya, Notaris tetap bertanggung jawab seumur hidup terhadap akta yang pernah dibuatnya. Hal ini didasarkan bahwa kehadiran Notaris untuk membuat akta otentik sebagai alat bukti sempurna bagi para pihak. Oleh karena itu, Notaris dalam membuat akta harus memenuhi standar prosedur, sehingga pertanggungjawaban Notaris terhadap akta yang dibuatnya harus melekat seumur hidup pada diri Notaris. Sehingga perlu diatur tentang perlindungan hukum bagi notaris dalam menjalankan tanggung jawabnya seumur hidup tersebut. 
Berkaitan dengan perlindungan hukum terkait werda notaris, dalam kasus Bapak Hamdani dengan nomor Putusan Perkara Pidana 336.Pid B.2017.PNslmn, hakim Wisnu menyatakan bahwa prinsip kehati-hatian memang perlu diterapkan khususnya dalam pembuatan akta notaris yang dibuatnya, supaya akta tersebut tetap sebagai alat bukti yang kuat dan sempurna dan tidak terjadi kesalahan baik aspek formal maupun materiil. Adanya unsur kewajiban kehati-hatian merupakan syarat agar seseorang dapat dikatakan telah melakukan suatu kesalahan. Yaitu merupakan kewajiban untuk bersikap tindak kehati-hatian terhadap korban (dari perbuatan melawan hukum) dengan tingkat kepedulian seperti seandainya jika manusia normal yang wajar akan melakukan dalam situasi yang serupa.

Meskipun perlindungan hukum terhadap werda notaris tidak diatur secara khusus dalam UUJN, namun masih tetap diperlukan perlindungan hukum bagi notaris yang telah berakhir masa jabatannya yaitu:

a. Hukum yang melindungi notaris dalam menjalankan tugas jabatannya yaitu ketentuan-ketentuan dalam UUJN, KUHPerdata dan peraturan perundangundangan lainnya. Perlindungan hukum dari regulasi/peraturan perundangundangan yaitu asas lex spesialis derogate legi generali (hukum yang khusus dimenangkan terhadap hukum yang umum) sehingga seharusnya UUJN yang jelas mengatur secara khusus diperuntukkan bagi notaris seharusnya dimenangkan terhadap KUHP (yang merupakan hukum yang berlaku umum) tetapi dalam prakteknya tidak demikian.

b. Perlindungan hukum notaris membentengi dirinya sendiri harus mentaati aturan dalam Pasal 15 ayat (2) sampai huruf c dan Pasal 16 ayat (1) huruf a UUJN. Selain itu notaris harus memenuhi beberapa unsur-unsur dalam membuat akta notaris, yaitu:

1) Unsur kejelasan artinya mulai dari judul akta harus mengandung/mencerminkan secara garis besar substansi dari isi akta, redaksi setiap pasal tidak boleh mempunyai arti lebih dari satu arti/bisa ditafsirkan lain, jangan berpindah ke pasal yang lain sebelum tuntas terkait dengan redaksi pasal tersebut dan memuat secara detail segala sesuatu yang memang harus diatur dalam akta/perjanjian tersebut.

2) Unsur kebenaran artinya sepanjang dimungkinkan mengupayakan kebenaran material. Hal demikian bisa diupayakan dengan pemberian 
nasehat hukum kepada para penghadap terjkait dengan akta yang akan dibuat dan dikemukkan akibat hukum dan sanksi dalam hal tidak mengemukakan atau menyampaikan segala sesuatu selain daripada yang sebenar-benarnya.

3) Unsur kelengkapan artinya kelengkapan disini mengandung pengertian jangan beranjak kepada pasal berikutnya sebelum pasal kelengkapannya benar-benar tuntas, sehingga dalam membuat akta atau menyusun sebuah akta harus memenuhi syarat kelengkapan dengan dokumen-dokumen, data serta subyek hukum pendukung harus dilengkapi terlebih dahulu sebelum membuat suatu akta dengan tidak boleh mengabaikan satupun data pendukung guna mendapatkan akta yang otentik tersebut.

4) Unsur keabsahan artinya penjelasan tentang keabsahan ini berarti tidak merupakan data yang dipalsukan, dengan cara setiap dokumen-dokumen pendukung sebelum dilakukannya pembuatan akta harus satu persatu di legalisir oleh pejabat yang berwenang agar terjadi kepastian hukum sejak dini sebelum masuk pembuatan akta.

c. Ketidakjelasan pengaturan mengenai batas pertanggungjawaban notaris terhadap akta otentik yang dibuatnya dalam Pasal 65.

UUJN akan menimbulkan pemahaman multitafsir sampai kapan beban tanggungjawab tersebut harus dipikul oleh notaris. Berkaitan dengan hal ini terdapat tiga bentuk penafsiran terhadap ketentuan yang terdapat dalam Pasal 65 UUJN, diantaranya adalah sebagai berikut :

1) Pertanggungjawaban notaris terhadap akta yang dibuatnya bergantung pada batas daluwarsa penuntutan dalam hukum pidana maupun perdata.

a) Pelanggaran terhadap ketentuan pidana yang hubungannya dengan memalsukan surat atau surat palsu dimana berdasarkan ketentuan Pasal 263 dan Pasal 264 KUHP ancaman hukumannya sekurang-kurangnya 6 tahun maka batas daluwarsa penuntutannya dikaitkan dengan ketentuan Pasal 78 ayat (1) angka 3 KUHP yang menyatakan bahwa tuntutan pidana akan hapus setelah 12 tahun terhadap tindak pidana yang diancam hukuman pidana penjara lebih dari 3 tahun. Jadi, dari ketentuan ini dapat dipahami bahwa setelah notaris berumur 77 tahun tidak dapat lagi dimintai pertanggungjawaban. Dengan asumsi notaris berakhir masa jabatannya pada usia 65 tahun ditambah dengan 12 tahun masa daluwarsa penuntutan.

b) Pelanggaran terhadap ketentuan perdata yang dikaitkan dengan ketentuan batas daluwarsa penuntutan secara perdata dalam Pasal 1967 BW dimana dinyatakan bahwa batas waktu penuntutan akan berakhir setelah lewat tenggang waktu 30 tahun. Jadi, setelah berumur 95 tahun maka notaris tidak dapat lagi dimintai pertanggungjawaban terhadap akta otentik yang dibuatnya. Dengan asumsi notaris telah berakhir masa jabatannya pada usia 65 tahun ditambah dengan batas waktu daluwarsa 30 tahun. 
2) Pertanggungjawaban notaris terhadap akta yang dibuatnya tidak memiliki batas daluwarsa dan berlaku seumur hidup.

Meskipun protokol notaris yang telah berhenti menjabat diserahkan kepada notaris lain yang ditunjuk oleh majelis pengawas daerah bukan berarti beban tanggungjawab terhadap sengketa yang muncul dikemudian hari terhadap akta yang dibuatnya juga berpindah ke notaris lain yang diserahi tanggung jawab. Oleh karena itu tanggungjawab notaris terhadap akta yang dibuatnya berlaku sepanjang notaris yang bersangkutan masih hidup walaupun telah berakhir masa jabatannya. Pertanggungjawaban notaris terhadap akta yang dibuatnya berlaku sepanjang belum berakhir masa jabatannya.

Pertanggungjawaban notaris terhadap akta otentik yang dibuatnya harus didasarkan pada konsep notaris sebagai jabatan. Dimana sepanjang notaris masih memiliki kewenangan untuk membuat akta, maka sepanjang itu pula tanggung jawab terhadap akta yang dibuat melekat dan dibebankan pada dirinya. Sehingga apabila notaris telah berhenti dari jabatannya baik berhenti secara sementara ataupun berhenti secara tetap, maka bersamaan dengan hal tersebut kewenangannya untuk membuat akta dibatasi dan berdampak juga pada lepasnya beban tanggung jawab yang dipikulnya terhadap setiap permasalahan yang muncul berkaitan dengan akta otentik yang dibuatnya.

Sehubungan dengan berakhirnya masa jabatan notaris, maka dalam hal pertanggungjawab terhadap akta yang dibuatnya, dapat mengacu kepada masa daluwarsa suatu dokumen sebagaimana ditentukan dalam Pasal 1967 KUHPerdata. Hal ini akan memberikan kepastian hukum bagi notaris tentang masa pertanggungjawabannya terhadap akta notaris yang dibuatnya. Artinya setelah lewat daluwarsa tersebut, walaupun notaris masih hidup, maka segala akibat hukum yang terjadi dari akta yang dibuatnya tersebut tidak dapat lagi dimintai pertanggungjawabannya.

Memperhatikan ketentuan UUJN, bahwa pertanggungjawaban notaris bukanlah terhadap isi akta yang dibuatnya, tetapi hanya terhadap prosedur dan tata cara pembuatan akta tersebut. Oleh karena itu sehubungan dengan ketentuan Pasal 63 ayat (5) UUJN bahwa protokol notaris yang telah berusia 25 
tahun atau lebih diserahkan kepada MPD, maka tanggung jawab notaris terhadap akta yang telah diserahkan kepada MPD seharusnya dibawah perlindungan MPD. Dalam hal ini MDP memberikan perlindungan terhadap notaris, terutama setelah berakhir masa jabatannya, karena akta yang telah dibuatnya sudah diserahkan kepada MPD. Hal ini memang masih perlu dikaji secara mendalam, karena menyangkut berbagai ketentuan dan peraturan perundang-undangan yang berkaitan.

Akta yang dibuat dihadapan Notaris digolongkan dalam dua macam akta yaitu akta partai dan akta pejabat. Dalam akta partai, Notaris dibebaskan dari tanggung jawab jika ternyata di kemudian hari apa yang diterangkan para penghadap tersebut tidak benar. Notaris menjamin bahwa penghadap benar menyatakan sebagaimana yang tertulis dalam akta namun Notaris tidak menjamin apa yang dinyatakan oleh penghadap tersebut adalah benar atau suatu kebenaran. Dalam hal ini Notaris hanya menuliskan apa yang diterangkan oleh para penghadap dan pada saat menuliskan tersebut telah ditanyakan kepada para penghadap tentang kebenaran keterangan masing-masing. Artinya jika di kemudian hari para pihak merasa dirugikan dengan isi akta tersebut, para penghadap tidak dapat menuntut pertanggungjawaban notaris, karena pada saat pembuatan akta tersebut, hal yang tertuang dalam akta tersebut sudah disetujui dan diakui para pihak sebagai suatu kebenaran. Sedangkan akta pejabat yang berisi tentang Berita Acara mengenai suatu kejadian yang dilihat dan didengar oleh Notaris itu sendiri. Dalam hal ini Notaris bertanggung jawab penuh atas kebenaran dari isi akta yang dibuatnya tersebut. Misalnya Berita Acara Rapat Umum Pemegang Saham suatu Perseroan. Dengan demikian Notaris tidak dapat diminta pertanggungjawaban terhadap kerugian yang timbul sebagai akibat dari pembuatan akta maupun persiapan dan pelaksanaannya sepanjang bantuan yang diberikan Notaris telah dilaksanakan sesuai dengan ketentuan UUJN, peraturan perundang-undangan lainnya dalam batas kecermatan yang wajar.

d. Untuk menentukan batas daluwarsa penuntutan secara pidana berkaitan dengan pemalsuan yang dilakukan notaris, maka hal tersebut harus didasarkan pada ketentuan Pasal 78 ayat (1) KUHP yang menetapkan bahwa hak menuntut 
secara pidana akan berakhir masa telah melampaui batas waktu tertentu. Berdasarkan Pasal 78 KUHP ayat (1), maka pemalsuan surat merupakan tindak pidana yang ancamannya di atas tiga tahun sehingga batas daluwarsa penuntutannya secara pidana adalah dua belas tahun. Sehingga setelah dua belas tahun berlalunya sebuah peristiwa pidana, maka tuntutan hukum terhadap tindak pidana yang dilakukan notaris tidak dapat dituduhkan lagi karena telah habis masa daluwarsanya.

e. Adanya bentuk pengayoman atau perlindungan hukum dari Ikatan Notaris Indonesia (INI) yaitu dari organisasi INI bagian pengayomannya harus dipilih Notaris senior atau werda notaris yang benar-benar profesional dan memberikan perlindungan dan mampu menjelaskan informasi akses hukum secara positif kepada penegak hukum yang sedang menyidik notaris. Kemudian perlindungan dari regulasi peraturan perundang-undangan yaitu berdasarkan asas "lex spesialis derogate legi generalie" (hukum yang khusus dimenangkan terhadap hukum yang umum) sehingga seharusnya UUJN yang jelas-jelas mengatur secara khusus diperuntukkan bagi notaris seharusnya dimenangkan terhadap KUHP (merupakan hukum yang berlaku umum), tetapi prakteknya tidak demikian.

INI memiliki bidang pengayoman yang salah satu tugasnya adalah mendampingi para notaris maupun ketika sudah werda, dalam kerangka profesi dengan persetujuan Majelis Pengawas, ketika dipanggil penyidik, penuntut hukum atau hakim. INI akan memberikan dukungan pendampingan agar oknum notaris bisa didudukkan dalam kerangka yang benar menyangkut profesinya sebagai pejabat umum yang diberikan kekuasaan oleh negara untuk menjalankan sebagaian dari tugas kenegaraan.

Ditinjau dari perspektif teori perlindungan hukum bahwa dengan dibatasinya pertanggungjawaban notaris terhadap akta yang dibuatnya berdasarkan batas daluwarsa penuntutan akan lebih menjamin adanya kepastian hukum mengenai sampai kapan seorang notaris harus bertanggung jawab terhadap akta yang dibuatnya. Dengan begitu rasa keadilan notaris tidak terciderai karena pembatasan tanggung jawab sangat bermanfaat bagi terwujudnya keamanan dan ketentraman hidup notaris dalam menjalani masa pensiunnya. 


\section{Penutup}

Berdasarkan pembahasan di atas, dalam penelitian ini disimpulkan bahwa: Pertama, pertanggungjawaban secara administrasi, perdata dan pidana. Pertanggungjawaban secara administrasi notaris dapat dimintakan melalui lembaga/organisasi notaris atau pengadilan melalui amar putusannya dapat meneruskan kepada organisasi notaris. Pertanggungjawaban tersebut muncul ketika kewajiban-kewajiban yang diatur dalam UUJN tidak diindahkan sebagaimana mestinya. Secara perdata, notaris dapat digugat di Pengadilan Negeri atau Pengadilan Agama ketika ada pihak yang merasa dirugikan atas tindakan Notaris yang membuat akta otentik tidak sesuai dengan ketentuan yang berlaku atau dilakukan secara melawan hukum. Sedangkan pertanggungjawaban secara pidana notaris ketika notaris turut serta melakukan atau membantu melakukan suatu tindak pidana, seperti memberikan keterangan palsu dalam akta notaris.

Kedua, tidak adanya kejelasan batas waktu pertanggungjawaban werda notaris atas akta yang dibuatnya sehingga perlu perlindungan hukum khusus bagi Notaris terutama bagi notaris yang tidak menjabat lagi (werda notaris). Selain itu, dalam UUJN tidak diatur secara khusus tentang perlindungan hukum bagi werda notaris. Bentuk perlindungan yang diperlukan bagi notaris yakni perlindungan dari notaris itu sendiri, regulasi peraturan perundang-undangan, pasal-pasal pidana daluwarsa penuntutan dan bagian pengayoman dari Ikatan Notaris Indonesia (INI).

Sesuai dengan kesimpulan tersebut, maka diberikan beberapa saran, sebagai berikut, pertama, perlu dilakukan pengaturan tentang pertanggungjawaban notaris terhadap akta yang dibuatnya setelah berakhir masa jabatannya dengan mempertimbangkan ketentuan peraturan dan perundang-undangan lainnya, sehingga memberikan kepastian hukum bagi werda notaris. Kedua, perlindungan hukum untuk werda notaris walaupun tidak diatur secara khusus dalam UUJN, tetapi notaris semasa dalam menjalankan tugas jabatannya wajib bertindak secara seksama, mandiri, jujur, professional dan kehati-hatian, agar tidak mudah dijadikan tergugat oleh pihak lain dan masuk kedalam ranah ancaman pidana. 


\section{Daftar Pustaka}

\section{Buku}

Adjie, Habib, Sekilas Dunia Notaris E PPAT Indonesia (Kumpulan Tulisan), CV Badar Maju, Bandung, 2009.

Sanksi Perdata dan Administrasi Terhadap Notaris Sebagai Pejabat Publik, PT Refika Aditama, Bandung, 2008.

(II), Sanksi Perdata dan Administratif Terhadap Notaris Sebagai Pejabat Publik, Refika Aditama, Bandung, 2008.

(I), Hukum Notaris Indonesia, Tafsir Tematik Terhadap Undang-Undang Nomor 30 Tahun 2004 tentang Notaris, Refika Aditama, Surabaya, 2007.

Anshori, Abdul Ghofur, Lembaga Kenotariatan Indonesia, UII Press, Yogyakarta, 2009.

Darus, M. Luthfan Hadi, Hukum Notariat dan Tanggungjawab Jabatan Notaris, UII Press, Yogyakarta, 2017.

Departemen Pendidikan Nasional, Kamus Besar Bahasa Indonesia, Gramedia Pustaka Utama, Jakarta, 2008.

Thoha, Miftah, Manajemen Kepegawaian Sipil di Indonesia, Kencana Press, Jakarta, 1999.

\section{Website}

http:/ /www.mediarakyat.co.id/2017/11/notaris-ceroboh-tidak-cermat-kerja.html diakses pada tanggal 20 November 2017 